\title{
The Syntax and Semantics of Wanting in Indonesian
}

\section{Citation}

Polinsky, Maria, and Eric Potsdam. 2008. The syntax and semantics of wanting in Indonesian. Lingua 118(10): 1617-1639.

\section{Published Version}

http://dx.doi.org/10.1016/j.lingua.2007.08.005

\section{Permanent link}

http://nrs.harvard.edu/urn-3:HUL.InstRepos:3382974

\section{Terms of Use}

This article was downloaded from Harvard University's DASH repository, and is made available under the terms and conditions applicable to Other Posted Material, as set forth at http:// nrs.harvard.edu/urn-3:HUL.InstRepos:dash.current.terms-of-use\#LAA

\section{Share Your Story}

The Harvard community has made this article openly available.

Please share how this access benefits you. Submit a story.

Accessibility 


\title{
The Syntax and Semantics of Wanting in Indonesian
}

\author{
Maria Polinsky and Eric Potsdam ${ }^{\mathrm{b}}$ \\ ${ }^{a}$ Department of Linguistics, Harvard University, Cambridge, Massachusetts 02138 U.S.A. \\ polinsky@fas.harvard.edu \\ ${ }^{\mathrm{b}}$ Linguistics Program, P.O. Box 115454, University of Florida, Gainesville, Florida 32611 \\ U.S.A. \\ potsdam@ufl.edu
}

The Indonesian verbs mau and ingin 'want' look like typical control verbs. When they are followed by a passive predicate however, an additional, unexpected interpretation arises. The sentence Siti mau/ingin di-cium oleh Ali means 'Siti wants to be kissed by Ali' but also 'Ali wants to kiss Siti'. We call the latter interpretation Crossed Control (CC). In CC, the wanter is not the surface subject of 'want' but an oblique element in the complement clause and the surface subject is the theme of the embedded predicate and not an argument of 'want'. For the syntax of CC, we reject clause union and backward control analyses and propose that 'want' in this construction is an auxiliary/raising verb that does not assign an external $\theta$-role. We propose that the control interpretation is encoded in the lexical semantics of the auxiliary. 'Want' takes a propositional argument but forces the volitional participant in this event to be construed as an experiencer of wanting. We hypothesize that this approach can be extended to volitional constructions in other languages.

key words: Indonesian; raising; restructuring; volitional predicates; want 


\section{Introduction}

This paper presents and analyzes the structure of a particular use of verbs of desire in Indonesian. Indonesian has two lexical items, mau and ingin, that translate as 'want, wish'. Two of their uses when followed by a complement clause are illustrated in (1) and (2).

(1) anak itu mau/ingin men-cium ibu

child that want ACT(IVE)-kiss mother

The child wants to kiss the mother.'

(2) anak itu mau/ingin di-cium oleh ibu

child that want PASS(IVE)-kiss by mother

a. 'The child wants to be kissed by the mother.' CONTROL READING

b. 'The mother wants to kiss the child.' CROSSED READING

Example (1) and example (2) with the meaning in (a) look like ordinary control verb structures (Vamarasi, 1999; Arka, 2000) and parallel their English translations. We will not be concerned with such sentences. This paper focuses on the second interpretation available for (2) in (b), which we will call the CROSSED CONTROL CONSTRUCTION (CCC). In this use, there are two overt arguments: the experiencer of the matrix verb 'want', which is also the agent of the embedded verb, and the theme of the embedded verb. The alignment of these arguments with their predicates, however, is "crossed". The experiencer shows up inside the embedded clause and the theme appears as the subject of the matrix clause. Note that the interpretation is not available for the corresponding English sentence: The child wants to be kissed by the mother cannot mean 
"the mother wants to kiss the child". This unusual use of 'want' in Indonesian has been noticed by a number of researchers (Sneddon, 1996; Arka, 2000; Musgrave, 2001; Gil, 2002).

The goal of this paper is to investigate the syntax and the semantics of the CCC. Before we turn to these analytical issues we would like to set the scene for the paper by showing that 'want' exhibits unusual behavior in English and other languages and that crossed control is found elsewhere in Austronesian. Our initial cross-linguistic considerations are offered in section 2. In section 3 we explore the syntax of the construction and argue against two analyses: a complex predicate analysis and a backward control analysis. We claim instead that 'want' is an auxiliary verb whose subject raises from the complement clause. Despite the fact that the sentence's meaning includes a 'wanter', it has no syntactic expression. In section 4 we attribute the unusual interpretation of the CCC to the semantics of 'want'. The essence of the proposal is that 'want' is akin to a subject-oriented adverb such as willingly. 'Want' does not assign a theamtic role to the volitional agent; however, like the adverb, it requires that one of the arguments in the sentence have this characteristic. It is able to identify this argument in its lexical semantics and further restrict it to being the experiencer of wanting. We implement the idea using a semantics for subject-oriented adverbs from Wyner (1998). Section 5 presents our conclusions and outlines questions that follow from this study.

\section{Cross-Linguistic Considerations}

'Want' and related verbs have been well-studied in numerous languages. It is repeatedly seen that 'want' shows unusual syntactic and/or semantic behavior, leading to a variety of proposals to account for the idiosyncrasies (Grimshaw, 1990; Belletti and Rizzi, 1988; Pesetsky, 1995, among many others). In English, for example, want is a pseudo-transitive verb: it takes a direct 
object and participates in an exceptional case marking pattern but as has been often observed it does not readily allow passivization: ${ }^{1}$

(3) a. Everyone wants chocolate.

b. *Chocolate is wanted by everyone.

(4) a. I want there to be a new rule.

b. We want Sandy to help with the proposal.

c. *Sandy is wanted to help with the proposal.

English 'want' is unlike other psych-predicates in allowing contraction to wanna (Lakoff, 1970; Postal and Pullum, 1978; Pullum, 1997, and many others), which indicates that it is a restructuring verb in some way (Goodall, 1991). Finally, in some non-standard English dialects, for example the Pittsburgh dialect illustrated in (5) (Tenny, 1998), want behaves more like an auxiliary and shows a unique pattern of raising not found in Standard English:

(5) The house wants painted by the owner.

(meaning: 'the house should be painted by the owner'

does not mean: 'the owner wants to paint the house')

${ }^{1}$ Den Dikken et al. (1996) propose an explanation for why 'want' does not passivize: 'want' takes a silent verb HAVE, which in turn takes a DP object (i). This object is inaccessible to passivization.

(i) want [vp HAVE [DP chocolate $]$ 
The dialect data suggest that want can be a raising verb, a tendency that we appeal to for Indonesian.

The behavior of 'want' is particularly well-studied in the Romance languages. 'Want' shows restructuring properties and is variously analyzed as a modal, an adverbial, a light verb, or a quasi-auxiliary (Strozer, 1981; Rizzi, 1982; Manzini, 1983; DiSciullo and Rosen, 1991; Picallo, 1990, and many others). This brief overview indicates that 'want' is thematically and syntactically very light. Again, our analysis of Indonesian will build on this line of analysis.

Within Austronesian, the crossed control construction is found in other languages. Parallel examples from Javanese, Tagalog (Paul Kroeger p.c.), Malagasy, Tukang Besi (Mark Donohue, p.c.), Tongan, and Samoan (Mosel and Hovdhaugen, 1992:715) are given in (6) through (11).

\section{Javanese}

bagian kalimat iki arep di-tegesake karo guru section sentence this want PASS-emphasize by teacher 'The teacher wanted to emphasize this part of the sentence.'

(7) Tagalog

?gusto siya ng halikan ni Pedro

want 3SG.NOM COMP kiss by Pedro

'Pedro wants to kiss her.' 
(8) Malagasy

te ho-vidi-n- dRasoa ilay fiara

want FUT-buy-PASS Rasoa that car

lit. "That car wants to be bought by Rasoa"

'Rasoa wants to buy that car.'

(9) Tukang Besi

ku-hada ku-peku-'e na 'obu

1SG-want 1SG-hit-3PATIENT NOM dog

lit. "The dog is wanted by me to be hit by me.'

'I want to hit a/the dog.'

(10) Tongan

'oku loto 'a Sione ke nau fakalangilangi-'i

PRES want ABS Sione COMP 3PL praise-PASS

'Sione wants to be praised by them.' (contra Otsuka, 2000:238)

'They want to praise Sione.' 
(11)

Samoan

afai e i ai se mai tigaina mai Atuā

if TMA exist DET sick hurt from Atuā

e fia aumai i le falema'i

TMA want bring to DET hospital

'If there is a seriously ill patient from Atuā,

whom one wants to bring to the hospital/

who wants to be brought to the hospital.'

In each case, the 'wanter' is expressed in the complement clause and the subject of the main clause is the theme of the embedded verb. Given that the pattern is found in other Austronesian languages and is not unique to Indonesian, a coherent and principled analysis is called for.

\section{Syntax}

In this section, we investigate the syntax of the CCC. We begin by laying out what we see the challenge to be. In a nutshell, the CCC seems to violate well-known locality requirements on $\theta$ role assignment because the experiencer, an argument of 'want', appears structurally in the complement clause. We propose three possible syntactic approaches to this problem. In the first, the Clause Union ANALYSIS, 'want' plus the following verb constitutes a complex predicate want-verb. The experiencer is therefore a local argument of the single (complex) predicate. The second analysis, couched in terms of CONTROL, appeals to the unusual pattern of backward control. In backward control the overt experiencer in the embedded clause is coindexed with an unpronounced representation of the experiencer in the clause containing 'want'. This 
unpronounced argument of 'want' makes $\theta$-role assignment local for 'want'. The configuration represents backward control because the overt controller is structurally inferior to the null controllee. Finally, our preferred syntactic analysis, the RAISING ANALYSIS, concludes that the thematic role problem is not actually a syntactic issue. The analysis ascribes a relatively conventional raising syntax to the CCC but at the expense of not solving the $\theta$-role puzzle. The solution will need to be sought elsewhere. In subsequent sections, we show that the Raising Analysis more adequately captures the syntax of the CCC despite its other shortcomings.

\subsection{The Clause Union Analysis ${ }^{2}$}

Under the Clause Union Analysis, the CCC contains one complex predicate consisting of two verbs, mau/ingin plus the main verb. This complex predicate can take two arguments, the agentive experiencer (the 'wanter') and the theme. For example, with the main verb cium 'kiss', the complex predicate is as follows:

$$
\text { mau cium 'want-kiss' }<\theta_{\mathrm{EXP}}, \theta_{\mathrm{THEME}}>
$$

To form the CCC, the complex predicate as a whole undergoes passivization, with the theme being realized as the surface subject and the experiencer being demoted to the by-phrase. This passivization is realized morphologically only on the lower verb, which is not unexpected given that mau and ingin are morphologically deficient in a number of ways (Vamarasi, 1999:141153). Similar analyses, which can be unified under the rubric of Clause Union, have been

\footnotetext{
${ }^{2}$ We are indebted to Peter Sells for suggesting to us that this analysis should be included in the paper.
} 
proposed for complexes involving 'want' in other languages, most notably in Spanish (Aissen and Perlmutter, 1983).

An argument in favor of the Clause Union analysis comes from the fact that the CCC allows only one temporal specification for the two verbs, as expected under complex predication.

(13) a. rumah itu mau/ingin di-hancurkan oleh mereka house that want PASS-destroy by 3PL

'They want to destroy that house.'

b. *kemarin rumah itu mau/ingin di-hancurkan oleh mereka minggu depan

yesterday house that want PASS-destroy by 3PL next week ('Yesterday they wanted to destroy this house next week.')

Several other facts seem to further support the Clause Union analysis: the second verb cannot be preceded by the complementizer untuk, or the adverb sangat 'very much', and some speakers allow clitic climbing as in (14b), where the clitic $k u$ ' $1 \mathrm{sG}$ ' appears before the first verb. These facts follow if the complex predicate $m a u+V$ is in some sense a single lexical item that cannot be separated in the syntax.

(14) a. kau mau ku=bunuh

2SG want $1 \mathrm{SG}=$ kill.PASS

b. \%kau $\mathrm{ku}=\mathrm{mau}$ bunuh

2SG $\quad 1 \mathrm{SG}=$ want kill.PASS

'I want to kill you.' 
As attractive as the Clause Union Analysis may be we find several problems with it. First, a crucial assumption in the Clause Union analysis is that 'want' can passivize but simply does not register passivization morphologically. Indonesian has two kinds of passive, the prefixal di- passive, which has appeared in a number of examples above, and a bare passive, seen in (14), and further illustrated in (15) (Chung, 1976; Sneddon, 1996; Vamarasi, 1999). In the latter, the embedded verb appears in an uninflected form and the passive agent is proclitic to the verb.

$$
\begin{aligned}
& \text { bagian kalimat ini dia=tegaskan } \\
& \text { section sentence this } 3 \mathrm{SG}=\text { emphasize } \\
& \text { 'This part of the sentence was emphasized by him.' }
\end{aligned}
$$

Mau and ingin by themselves cannot be passivized using either of these strategies. A sentence with mau/ingin followed by a DP complement, (16), or a VP complement, (17), does not passivize regardless of the strategy used: ${ }^{3}$

\footnotetext{
${ }^{3}$ Mau/ingin are what Vamarasi (1996:146-148) calls pseudo-transitive. Although followed by a DP, mau+ DP does not behave like a transitive structure.
} 
(16) a. mereka ingin rumah ini

3PL want house this

'They want this house.'

b. *rumah ini di-ingin oleh mereka

house this PASS-want by 3PL

('This house is wanted by them.')

c. *rumah ini mereka=ingin

house this $3 \mathrm{PL}=$ want

('This house is wanted by them.')

(17) a. anak itu mau/ingin men-cium ibu

child that want ACT-kiss mother

The child wants to kiss the mother.'

b. *men-cium ibu mau/ingin oleh anak itu

ACT-kiss mother want by child that

('To kiss the mother is wanted by the child.')

c. *men-cium ibu dia=mau/ingin

ACT-kiss mother $3 \mathrm{SG}=$ want

('To kiss the mother is wanted by him.')

Given these facts it is surprising that mau/ingin should be able to undergo passivization when it is part of a complex predicate. 
The second argument against the Clause Union Analysis comes from the fact that 'want' and the main verb have independent syntactic existences. In (18), they can have their own separate negations.

(18) a. rumah itu tidak mau/ingin di-hancurkan oleh mereka house that NEG want PASS-destroy by 3PL 'They don't want to destroy that house.'

b. anak-anak mau tidak di-belikan sepeda oleh ibu children want NEG PASS-buy bicycle by mother 'The mother wants to not buy bicycles for the children.'

Similarly, mau can be deleted independently from the main verb in a gapping-like ellipsis construction: ${ }^{4}$

mobil ini mau di-jual oleh Ali dan sepeda itu
car this want PASS-sell by Ali and bicycle that
mat di-beli oleh Siti
want PASS-buy by Siti

'Ali wants to sell this car, and Siti, to buy that bicycle.'

The material following mau can also be deleted in a construction that Lobeck (1992) likens to VP ellipsis:

\footnotetext{
${ }^{4}$ For reasons that we do not understand, deletion of the main verb alone is degraded.
} 


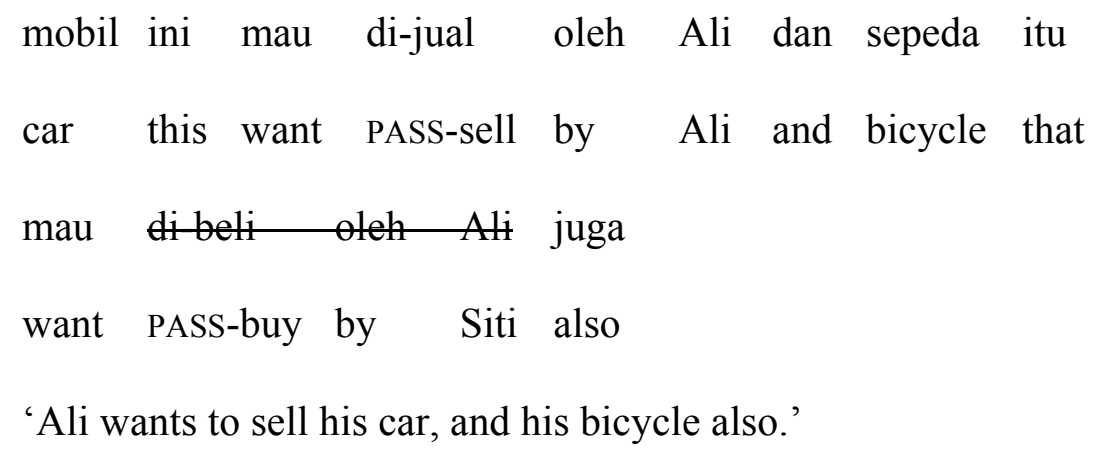

'Ali wants to sell his car, and his bicycle also.'

This is surprising if the two verbs form a single lexical unit. Their separability argues against the Clause Union Analysis.

The third argument against Clause Union comes from the distribution of the emphatic (foregrounding) particle -lah. This particle, whose semantics is rather subtle, attaches to the first constituent of a complex predicate according to Sneddon (1996:261-3):

(21) a. dapat-lah di-simpulkan bahwa ... can-EMPH PASS-conclude that 'It can be concluded that...'

b. *dapat di-simpulkan-lah bahwa ... can PASS-conclude-EMPH that

If the CCC involved a complex predicate, -lah should only attach to mau and not the following main verb. This prediction is not borne out however. -Lah can attach to either verb and (22b) is grammatical, in contrast to the ungrammatical (21b). 
(22) a. kamis ini buku itu mau-lah di-beli oleh Siti

Thursday this book that want-EMPH PASs-buy by Siti

'Siti actually wants to buy that book on Thursday.'

b. kamis ini buku itu mau di-beli-lah oleh Siti

Thursday this book that want PASS-buy-EMPH by Siti

'Siti wants to actually buy that book on Thursday.'

Based on these data we reject the complex predicate analysis for Indonesian. Such an analysis may work for the syntax of wanting in other languages but for the case at hand we need to consider other alternatives.

\subsection{The Control Analysis}

Given our rejection of the Clause Union Analysis in which the two verbs have a unified argument structure, we turn to an alternative in which each verb retains its own argument structure. In such an approach, mau/ingin 'want' will have an experiencer external argument representing the 'wanter' and a clausal complement corresponding to the event wanted. The embedded verb cium 'kiss' will have its two arguments, an agent and a theme- the kisser and the person being kissed, respectively. We can represent this state of affairs with the lexical entries in (23).

(23) a. mau/ingin 'want' $<\theta_{\mathrm{EXP}}, \theta_{\mathrm{EVENT}}>$

b. cium 'kiss' $\quad<\theta_{\mathrm{AGT}}, \theta_{\mathrm{THEME}}{ }^{>}$ 
In an ordinary control construction involving these two verbs, (24), there are four $\theta$-roles but only three overt argument XPs. One argument is not expressed. The missing argument corresponds to the embedded clause subject, which is realized as PRO and coindexed with the matrix subject in the Government-Binding tradition. Here and below we ignore the event $\theta$-role of 'want'.

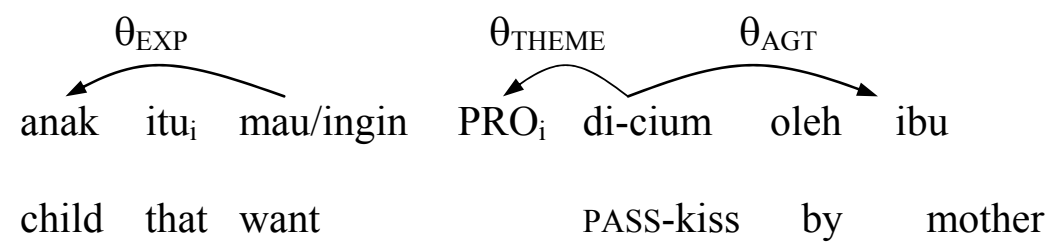

'The child wants to be kissed by the mother.'

Such a structure is motivated by familiar assumptions about the linking between $\theta$-roles and syntactic positions. The Theta Criterion in (25) requires that every $\theta$-role be assigned to exactly one argument XP and that every argument XP be assigned exactly one $\theta$-role. In addition, $\theta$-role assignment is local, (26). A common Government-Binding assumption is that a predicate may only assign $\theta$-roles to XPs within its clause, specifically, those that it governs.

(25) Theta Criterion (Chomsky, 1981)

a. each argument bears exactly one $\theta$-role

b. each $\theta$-role is assigned to exactly one argument

(26) Locality of $\Theta$-Role Assignment

$\theta$-roles are assigned under government

Returning to the CCC in (27), two problems arise under this view. 
anak itu mau/ingin di-cium oleh ibu

child that want PASS-kiss by mother

'The mother wants to kiss the child.'

First, both 'want' and the embedded verb need to assign $\theta$-roles to 'mother'; however, there is only one syntactic representation of this participant. It would violate the Theta Criterion to assign two $\theta$-roles to this XP. Further, assignment of mau's experiencer $\theta$-role to 'mother' would violate Locality on the assumption that the agent is syntactically in the complement clause. Second, the matrix subject is an argument of the embedded predicate but it does not occur local to the embedded predicate, again in violation of Locality.

Parallel to the introduction of PRO in ordinary control, the first problem must be solved by introducing an empty category (EC) in the matrix clause to bear the experiencer $\theta$-role. We assume that this empty category would be the external argument and hence the subject of the clause. It will occupy spec,IP.

The second problem can be solved by having the initial DP move from the embedded clause into the matrix clause. It receives the theme $\theta$-role locally in the embedded clause before movement. Since spec,I is occupied by the experiencer EC, the movement must be an instance of A'-movement. We will assume that it is to a position outside the clause. ${ }^{5} \mathrm{~A}$ tree might look like the following, where XP is some A' projection in the left periphery. The structure satisfies both the Theta Criterion and Locality.

\footnotetext{
${ }^{5}$ This movement will need to be obligatory, as the CCC is ungrammatical if the theme remains in a lower position.
} 
(28)

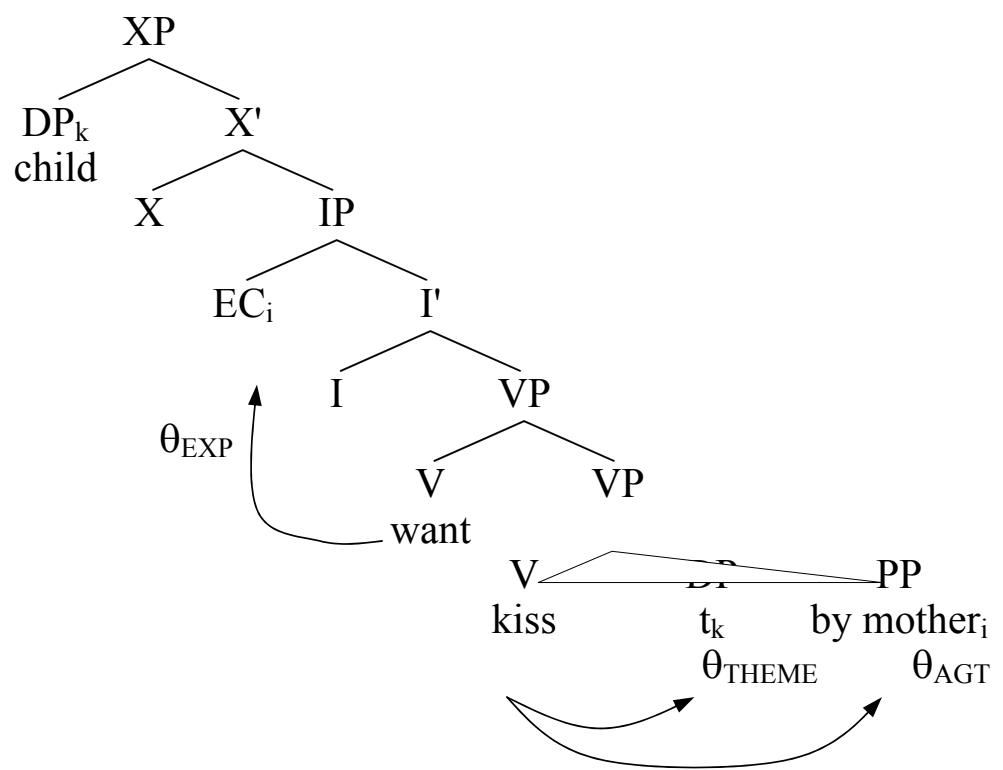

Such a structure instantiates backward control (Polinsky and Potsdam, 2002): an overt argument in a complement clause is coindexed with and determines the interpretation of a silent expression in a higher clause. This is the opposite of the ordinary control relationship between the empty category and its antecedent seen in (24). ${ }^{6}$ In summary, we can bring the CCC within the bounds of normalcy with respect to Theta Theory by assigning it a less common but otherwise attested syntactic derivation.

The Control Analysis adequately captures the fact that the CCC is associated with selectional restrictions that are standard in control structures:

${ }^{6}$ For the sake of argument, we will ignore how the empty category comes to be coindexed with the lower argument. Since we will reject this hypothesis on other grounds, solving this issue is not relevant to the following discussion. 
(29) a. kota ini di-hancurkan oleh api

town this PASS-destroy by fire

'This town was destroyed by fire.'

b. \#kota ini mau/ingin di-hancurkan oleh api

town this want PASS-destroy by fire

'\#Fire wants to destroy this town.'

The two ingredients of the Control Analysis are as follows:

(30) a. there is a null representation of the experiencer in the matrix clause subject position that receives a $\theta$-role from 'want'

b. the embedded theme undergoes $A^{\prime}$-movement into the matrix clause and is not the matrix subject

However, it turns out that these claims are incorrect. We start with (30a). In general, providing evidence for the silent element in the matrix clause co-indexed with an overt DP in the lower clause is crucial for establishing backward control, and the more compelling cases of backward control, such as Tsez (Polinsky and Potsdam, 2002) or Malagasy (Potsdam, 2006), rely on such evidence. In Indonesian, binding facts suggest that there is no empty category.

Arka and Manning (1998) shows that the passive agent in Indonesian cannot bind a pronoun in the subject position. The example below indicates that the passive agent does not ccommand the base or surface positions of the theme. 
(31)

$$
\begin{aligned}
& {\text { surat-nya } *_{i, j} \text { di-baca oleh }}_{\text {semua-orang }}{ }_{i} \\
& \text { letter-3SG PASS-read by all-person } \\
& \text { 'His } *_{i, j} \text { letter was read by each person }{ }_{\mathrm{i}} \text {.' }
\end{aligned}
$$

The same binding restriction is found in the CCC, as illustrated by (32):

$$
\begin{aligned}
& {\text { surat-nya } *_{i, j} \text { mau di-baca oleh semua-orang }}_{i} \\
& \text { letter-3SG want PASS-read by all-person } \\
& \text { 'Each person }{ }_{i} \text { wants to read his } *_{i, j} \text { letter.' }
\end{aligned}
$$

This is unexpected under the Control Analysis in which there is an empty category in the matrix clause and therefore the pronoun is bound prior to $\mathrm{A}^{\prime}$-movement:

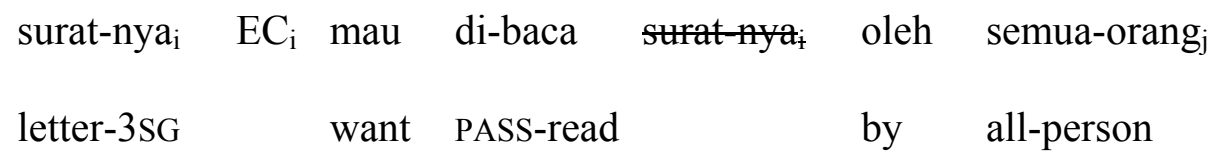

(34) shows that an $\mathrm{A}^{\prime}$-fronted element can otherwise be bound from within the clause via reconstruction.

surat-nya $_{i} \quad$ semua-orang $_{i}$ membaca surat nya
letter-3SG all-person ACT-read
'His ${ }_{i}$ letter, everyone ${ }_{i}$ read.'


The Control Analysis therefore does not account for the ungrammatical bound pronoun reading in (32). If there is no empty category, however, the facts follow. ${ }^{7}$

The evidence against the claim in (30b) is even more compelling. We discuss a range of arguments below. In each case, we show that a particular generalization holds of subjects but not A'-fronted elements. The initial DP in the CCC behaves like a subject according to each diagnostic.

Subjects in Indonesian are not subject to discourse restrictions often associated with topics or A'-moved elements (Sneddon, 1996:254-6; Chung, this volume). Subjects, for example, can be non-specific or quantificational, (35a) from Sneddon (1996:134), while fronted elements may not be, (35b).

(35) a. sebagian dari transmigran itu sudah tahu tentang persawahan a.number of transmigrants those PERF know wet.rice.cultivation 'A number of the transmigrants know about wet rice cultivation.'

b. *apa-apa tidak membaca Ali anything NEG ACT.read Ali ('Ali does not read anything.')

The initial DP in the CCC patterns with subjects and is not restricted:

${ }^{7}$ Wechsler and Arka (1998) argues that binding is not based on c-command in the related language Balinese. If this is correct, then this argument might not stand. 
(36)

tidak setiap kata ingin di-ucapkan oleh murid itu

NEG every word want PASS-say by student that

'The student does not want to say every word.'

Yes-no question particles also help to identify subjects. They appear before the subject in ordinary SVO clauses (Sneddon, 1996:321):

$\begin{array}{lll}\text { bukankah } & \text { saudara } & \text { kaya? } \\ \text { Q } & \text { 2SG } & \text { rich }\end{array}$

'Isn't it the case that you are rich?'

In the CCC, the particles occur in this same position, (38), if we take the initial DP to be the subject. This contrasts with topical left-periphery constituents. These elements preferably precede the question particle, (39).

(38) a. bukankah bagian kalimat ini mau di-tegaskan-nya?

Q section sentence this want PASS-explain-3SG

'Did he want to explain this part of the sentence?'

b. *bagian kalimat ini bukankah mau di-tegaskan-nya? ${ }^{8}$

section sentence this Q want PASS-explain-3SG

${ }^{8}$ An anonymous reviewer finds this example to be grammatical with the initial NP interpreted as a topic. In support of the topic interpretation, one of our consultants accepted this sentence with a marked pause between the initial DP and the question particle. 
(39) a. *bukankah kamis ini Siti mau membeli buku itu?

Q Thursday this Siti want buy book that

b. kamis ini bukankah Siti mau membeli buku itu?

Thursday this Q Siti want buy book that

'Does Siti want to buy that book on Thursday?'

A further, well-known test for subjects in Indonesian is that they can be clefted in a question or focus construction (Vamarasi, 1999; Cole, Hermon, and Tjung, 2005). A cleft is formed by placing the particle yang between the initial clefted constituent and the rest of the clause. Simplifying things somewhat, this option is generally not available to non-subjects (Sneddon, 1996:285-291; Saddy, 1991, and others). ${ }^{9}$ (40) shows that clefting is possible with the CCC, providing evidence that the initial DP is a subject.

a. apa yang mau di-tegaskan oleh guru?

what COMPwant PASS-emphasize by teacher

'What did the teacher want to emphasize?'

b. bagian kalimat ini yang mau di-tegaskan-nya section sentence this COMPwant PASS-emphasize-3SG

'It's this part of the sentence that he wants to emphasize.'

On the other hand, Indonesian also permits wh-in-situ for questions; however, for many speakers it is not available to subjects (Sneddon, 1996:317; Saddy, 1991).

${ }^{9}$ See Cole and Hermon (2005) for the discussion of dialectal variation and various complications concerning this general claim. 
(41) a. dia men-ulis apa?

he ACT-write what

'What did he write?'

b. *siapa men-ulis buku ini?

who ACT-write book this

('Who wrote this book?')

Wh-in-situ is also not possible with the CCC, which follows if the initial DP is a subject:

*apa mau di-tegaskan-nya?

what want PASS-emphasize-3SG

('What did he want to emphasize?')

Another argument for the subject status of the initial DP comes from depictives. Simple examples of depictives are given in (43), which suggest that depictives are only licensed by subjects and not by non-subjects or fronted elements.

(43) a. mereka $a_{\mathrm{i}}$ mem-ukul anak-anak bersama-sama $_{\mathrm{i},{ }_{\mathrm{j}}}$

they $\quad$ ACT-hit children together

b. anak-anak mereka $_{\mathrm{i}}$ mem-ukul bersama-sama ${ }_{\mathrm{i},{ }_{\mathrm{j}}}$

children they ACT-hit together

' They $_{\mathrm{i}}$ hit the children together $_{\mathrm{i},{ }^{*} \mathrm{j}}$ '

(44) shows that depictives associated with the initial DP in the CCC are allowed, again supporting the subject analysis and arguing against the A'-fronted element analysis. 


$\begin{array}{llllll}\text { buku-buku }_{j} & \text { mau } & \text { di-baca } & \text { oleh para murid } & \text { bersama-sama }_{j} \\ \text { books } & \text { want } & \text { PASS-read } & \text { by } & \text { students } & \text { together }\end{array}$

'The students want to read the books together $_{\mathrm{j}}$ '

Finally, Indonesian is known to allow VOS word order (Chung, this volume; Sneddon, 1996:257). If the initial DP is a subject it should be able to appear at the end of the clause. This prediction is borne out:

a. mobil ini mau di-jual-nya
car this want PASS-sell-3SG
b. mau di-jual-nya mobil ini
want PASS-sell-3SG car this
'He wants to sell this car.'

Such an option would presumably not be available for A'-moved elements under the assumption that the $\mathrm{A}^{\prime}$-position is clause-initial or at least occurs on the left periphery of the clause. We conclude that the initial DP in the CCC is the subject of its clause and the Control Analysis cannot be maintained.

\subsection{The Raising Analysis}

Having excluded Clause Union and Control Analyses, we turn to our preferred solution. The preceding discussion has yielded the following conclusions about the CCC:

(46) a. mau must be a distinct head in the syntax

b. the initial DP (theme) is the subject of the clause 
A syntactic analysis of the CCC compatible with these findings is that mau/ingin are simple raising auxiliary verbs with no external argument. We call this the Raising Analysis and the derivation of a CCC example proceeds as in (47).

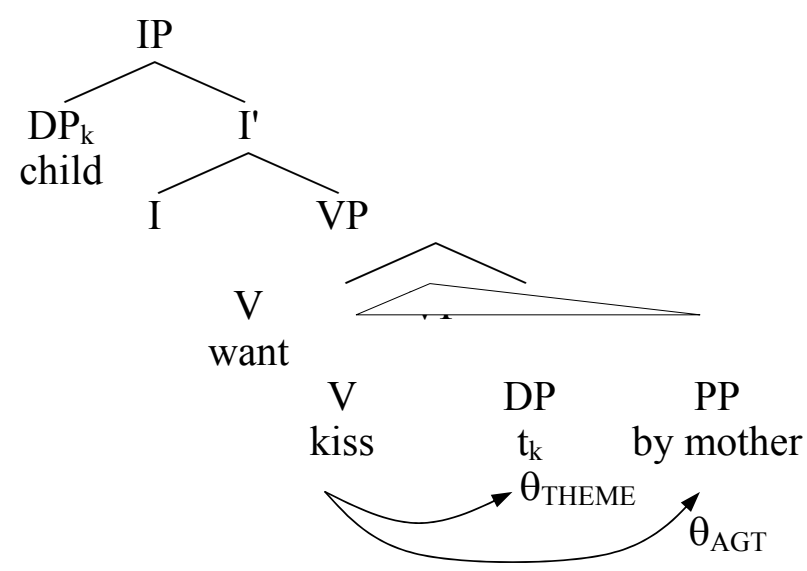

In this structure, 'want' is a verbal head in the syntax that takes a reduced clausal complement, which we represent as a VP. The theme of the embedded verb undergoes A-movement to spec,I. The drawback to this structure is that there is no syntactic representation of the 'wanter' and we do not capture the selectional restriction facts in (30) and the interpretation that the embedded agent in the $\mathrm{CCC}$ is the wanter. We will return to this problem after demonstrating that a raising syntax is nevertheless more desirable than that posited under the Clause Union and Control Analyses.

It should be clear from the Raising analysis why the initial DP has subject characteristics, as shown in the previous section: because it is a derived subject. In the remainder of the section we show that mau/ingin also have characteristics of raising verbs.

(48) lists ways in which mau/ingin in the CCC are syntactically restricted. In English, these properties are shared by raising verbs and finite auxiliaries. The properties suggest that mau/ingin are raising verbs and/or they have a reduced complement structure. This is captured in 
our structure by making the complement of mau/ingin a VP rather than something larger, such as IP or CP. We illustrate the observations below.

(48) characteristics of mau/ingin
a. do not passivize
b. do not embed under a control complement
c. do not form an imperative
d. do not combine with other auxiliaries
e. do not allow an independent temporal specification for its complement
f. do not allow the complementizer untuk in complement clause
g. do not allow the complement clause to be fronted

We already saw that mau/ingin do not passivize, (16) and (17). (49) shows that they do not occur embedded under uncontroversial control verbs, even if the meanings of the respective verbs are compatible: ${ }^{10}$

$\begin{array}{llll}\text { *anak ini mencoba mau di-ajar } & \text { Bahasa Inggris oleh } & \text { Ali } \\ \text { child this try } \quad \text { want PASS-teach English } & \text { by } & \text { Ali } \\ \text { ('The child tried for Ali to want to teach him English.') } & & \end{array}$

This fact might indicate two things. First, raising verbs are also known to resist embedding under control verbs, so the data point could be construed as supporting the Raising Analysis. Second,

\footnotetext{
${ }^{10}$ See Vamarasi (1999:145) for co-occurrence of Indonesian auxiliaries and auxiliary-like verbs.
} 
finite verbs also are generally ruled out in this context. Further investigation is needed to determine which, if either, of these properties underlies the ungrammaticality of (49).

Mau/ingin also do not form imperatives:

$$
\begin{aligned}
& \text { *ingin(-lah) di-baca surat ini! } \\
& \text { want-EMPH PASS-read letter this } \\
& \text { ('Be willing to read this letter!') }
\end{aligned}
$$

Here too, the problem could be due to the finiteness of the verbs or to the inherent incompatibility of imperatives with the semantics of volitional predicates.

Mau/ingin do not combine with other auxiliaries such as bisa 'can', perlu 'must', boleh 'may', and others. This is illustrated in (51). A possible explanation for this co-occurrence restriction is that there is a dedicated head position for auxiliaries, such as $\mathrm{I}^{\circ}$, and only one element can occur in this position. This was not encoded in our structure.

$$
\begin{aligned}
& \text { *mereka sempat/bisa/perlu/boleh/suka mau di-tolong oleh Ali } \\
& \text { 3PL have the opportunity/can/must/may/like want PASS-help by Ali } \\
& \text { ('Ali has a chance/can/must/may/would like to want to help them.') }
\end{aligned}
$$

Three further observations support the reduced complement clause that we propose. We already saw in (13b) that CCC examples allow only one temporal specification for the two verbs, indicating that there is only one event (see Wurmbrand (2003) for discussion of this diagnostic): 
(52)

a. rumah itu mau/ingin di-hancurkan oleh mereka

house that want PASS-destroy by 3PL

'They want to destroy that house'

b. *kemarin rumah itu mau/ingin di-hancurkan oleh mereka minggu

depan

yesterday house that want PASS-destroy by 3PL next week

('Yesterday they wanted to destroy this house next week.')

The complement clause cannot be introduced by the complementizer untuk, which is normally optional with control complements (Arka, 2000).

$$
\begin{aligned}
& \text { bagian kalimat ini mau (*untuk) di-tegaskan-nya } \\
& \text { section sentence this want COMP PASS-emphasize-3SG } \\
& \text { 'He wants to emphasize this part of the sentence.' }
\end{aligned}
$$

Lastly, the complement clause is inert for movement. It cannot be fronted or focused in a cleft, which is surprising given that complement clauses in general undergo this type of movement in Indonesian (Arka, 2000; Vamarasi, 1999):

$$
\begin{aligned}
& \text { *[di-cium oleh ibu } \text { (yang) mau/ingin anak itu } \\
& \text { PASS-kiss by mother COMP want child that } \\
& \text { ('The mother wants to kiss the child.') }
\end{aligned}
$$

From these data we conclude two things: mau/ingin belong to the class of raising/auxiliary verbs in Indonesian, at least in the CCC use. They also take a reduced clausal complement which limits the kind of material that can appear following mau/ingin. We have 
captured this latter fact by categorizing this complement as a VP. Our analysis is thus very similar to Aissen's (1994) proposal for Tzotzil auxiliaries, with the difference that in Tzotzil, the auxiliary occurs with an expletive subject. It is also similar to Cinque's (2004) analysis of Italian. The central point of our analysis is that mau/ingin lack an external argument and the associated syntax is one of raising. This leaves us with the puzzle we started with, where does the control-like interpretation come from? We will address this puzzle in the next section.

\section{Semantics}

The previous sections concluded that the $\mathrm{CCC}$ repeated below involves a raising syntax.

anak itu mau/ingin di-cium oleh ibu
child that want PASs-kiss by mother

'The mother wants to kiss the child.'

Mau/ingin has no external argument and its surface subject has raised from the complement clause. There is no experiencer $\theta$-role in the structure. However, 'want' genuinely seems to place selectional restrictions on the embedded agent. As we have already seen, inanimate elements in the by-phrase are judged anomalous:

(56) a. kota ini di-hancurkan oleh api

town this PASS-destroy by fire

'This town was destroyed by fire.'

b. \#kota ini mau/ingin di-hancurkan oleh api

town this want PASS-destroy by fire

'\#Fire wants to destroy this town.' 
The question is how 'want' can semantically restrict the embedded agent without assigning it a $\theta$-role. We propose that it does so via its lexical semantics. In this section we develop our analysis of the semantics of 'want'. We point out a similarity between 'want' and subjectoriented adverbs in section 4.1 and develop a formal analysis in section 4.2.

\subsection{Subject-Oriented Adverbs}

Building on the observation that mau/ingin are not full verbs and on the well-known fact that verbs and adverbs often form contiguous classes, we explore the idea that mau/ingin have much in common semantically with subject-oriented adverbs in English such as deliberately, reluctantly, willingly, etc. These adverbs are known to introduce a thematic dependency with a local argument similar to what was seen above with 'want'. In this section we lay out the relevant behavior of English subject-oriented adverbs and highlight the parallel with mau/ingin that we will build on.

Jackendoff (1972) recognized a subset of S-adverbs that he called subject-oriented adverbs (see also McConnell-Ginet, 1982; Wyner, 1994, 1998; Ernst, 2002, and others). We will use Wyner's (1998) label THEMATICALLY DEPENDENT ADVERB (TDA) for the class of adverbs that includes purposely, reluctantly, willingly, and others. TDAs have the unusual characteristic of ascribing some semantic property, such as willingness, to the subject of the sentence. In (57a), willingness is ascribed to Barbara. In (57b), willingness is ascribed to Madonna.

(57) a. Barbara willingly interviewed Madonna.

b. Madonna willingly was interviewed by Barbara. 
TDAs also show so-called PASSIVE SENSITIVITY, whereby they ascribe some property to the agent in a passive sentence. In the passive sentences in (58), willingness can be ascribed to Barbara, even though Barbara is not the subject of the clause. ${ }^{11}$

(58) a. Madonna was willingly interviewed by Barbara.

b. The interview was willingly cancelled by Barbara.

A number of semantic analyses of TDAs exist in the literature (McConnell-Ginet, 1982; Wyner, 1994, 1998; Ernst, 2002; and others). What they all share is that that the thematic dependency introduced by the adverb is not captured using syntactic $\theta$-roles but, instead, is done in the lexical semantics of the adverb.

Wyner (1998), whose analysis we will ultimately follow, argues that linguistic theory needs to recognize both $\theta$-ROLES and THEMATIC PROPERTIES. $\Theta$-roles are syntactic objects governed by syntactic principles. As codified in the Theta Criterion, (25), every argument receives exactly one $\theta$-role and every predicate assigns exactly as many $\theta$-roles as it has arguments. Thematic properties, on the other hand, are sub-aspects of $\theta$-roles. $\Theta$-roles like Agent and Theme are made up of prototypical thematic properties (Dowty, 1991). An argument bearing the Agent $\theta$-role has all (or at least most) of the thematic properties in (59).

\footnotetext{
${ }^{11}$ An anonymous reviewer points out that there are two patterns here: subject sensitivity in (57) and agent sensitivity in (58). As our analysis will make clear, we eventually assume that both classes are subsumed by the label agent sensitivity. Subject sensitivity arises when the agent happens to be the subject.
} 
proto-Agent properties (Dowty, 1991:572)
a. volitional involvement in the event/state
b. sentience (and/or perception)
c. causing an event or change of state in another participant
d. movement (relative to the position of another participant)

Thematic properties are not governed by the Theta Criterion.

The parallel between TDAs and mau/ingin in the CCC is that both ascribe some semantic property to an agent of the event they are embedded in. In the TDA examples above, the adverb willingly ascribes willingness to the agent of the sentence, independent of its syntactic realization. In the Indonesian $\mathrm{CCC}$ example below, 'want' ascribes a desire to the agent of the clause, 'teacher'.

$$
\begin{aligned}
& \text { bagian kalimat ini mau di-tegaskan oleh guru } \\
& \text { section sentence this want PASS-emphasize by teacher } \\
& \text { 'The teacher wants to emphasize this part of the sentence.' }
\end{aligned}
$$

Wyner $(1994,1998)$ provides an analysis of TDAs that allows them to assign a thematic property to an Agent in the clause without assigning it a $\theta$-role. Although we will not review Wyner's analysis of TDAs here, we use it below for the Indonesian case.

\subsection{A Semantics for 'Want'}

This section proposes a semantics for mau/ingin that accounts for the unusual interpretation of the CCC. We first present an analysis of simple clauses without mau/ingin. We then offer a 
semantics for the auxiliary verbs that combines with the semantics of the simple clauses to account for the interpretation of the CCC.

Wyner adopts an event-based semantics (Parsons, 1990; Davidson, 2001). Within such a framework, the passive and active sentences in $(61 \mathrm{a}, \mathrm{b})$ have the semantic representation in (61c).

(61) a. ibu men-cium anak itu mother ACT-kiss child that

'The mother kissed the child.'

b. anak itu di-cium oleh ibu child that PASs-kiss by mother 'The child was kissed by the mother.'

c. $\exists$ e [kissing $(e) \& \operatorname{Agent}(\mathrm{e})=$ mother $\&$ Theme $(\mathrm{e})=$ child $]$

d. $\exists$ e $[\operatorname{kissing}(e) \& \operatorname{Agent}(\mathrm{e})=$ mother $\&$ volition $(\mathrm{e})=$ mother $\&$ Theme $(\mathrm{e})=$ child $]$

The formula in (61c) says that there is an event that is a kissing event, that the agent of this event is the mother, and that the theme of this event is the child. Because a proto-typical Agent has the volitional thematic property given Dowty's proto-Agent properties, we can expand (61c) to (61d) and make the volitional participant explicit without harm.

We now need to connect to the syntax of these sentences. For the active, the structure is as in (62) (English words substituted). The surface subject originates in a VP-internal position, which we identify as spec, $\mathrm{V}$ for simplicity. It then raises to spec,I. 
(62)

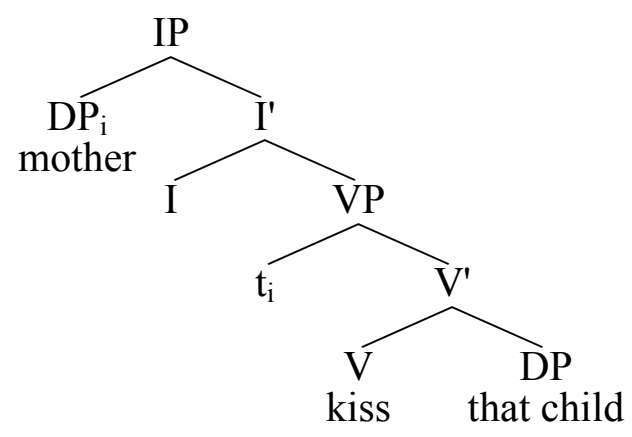

The corresponding semantic calculation is in (63). Kiss has two arguments plus an event argument, the interpretation in (63a). Kiss combines semantically with the object, the child, translated as c, to yield the $\mathrm{V}^{\prime}$ in $(63 \mathrm{~b})$. The trace in spec, $\mathrm{V}$ is translated as a free variable, which will ultimately be bound by the raised subject. The VP has the interpretation in (63c). Following Heim and Kratzer (1998), the raised subject introduces a lambda abstraction operator below spec,I which binds the variable corresponding to the raised subject. I' has the interpretation in (63d), in which a lambda operator has been reintroduced to bind the free variable. The IP thus receives the interpretation in (63e), where $\mathrm{m}$ is a constant interpreted as the mother. Finally, existential closure binds the event variable once all arguments have been introduced, (63f). 
(63) a. kiss $\lambda y \lambda x \lambda \mathrm{e}[\operatorname{kissing}(\mathrm{e}) \& \operatorname{Agent}(\mathrm{e})=\mathrm{x} \&$ Theme $(\mathrm{e})=\mathrm{y}]$

b. $V^{\prime} \quad \lambda y \lambda x \lambda e[\operatorname{kissing}(e) \& \operatorname{Agent}(e)=x \&$ Theme $(e)=y](c) \rightarrow$

$\lambda x \lambda e[\operatorname{kissing}(e) \& \operatorname{Agent}(e)=x \& \operatorname{Theme}(e)=c]$

c. VP $\lambda x \lambda$ e $[\operatorname{kissing}(\mathrm{e}) \& \operatorname{Agent}(\mathrm{e})=\mathrm{x} \&$ Theme $(\mathrm{e})=\mathrm{c}](\mathrm{z}) \rightarrow$

$\lambda \mathrm{e}[\operatorname{kissing}(\mathrm{e}) \& \operatorname{Agent}(\mathrm{e})=\mathrm{z} \& \operatorname{Theme}(\mathrm{e})=\mathrm{c}]$

d. I' $\quad \lambda z \lambda e[\operatorname{kissing}(e) \& \operatorname{Agent}(e)=z \&$ Theme $(e)=c]$

e. IP $\quad \lambda z \lambda e[$ kissing $(\mathrm{e}) \& \operatorname{Agent}(\mathrm{e})=\mathrm{z} \&$ Theme $(\mathrm{e})=\mathrm{c}](\mathrm{m}) \rightarrow$

$\lambda \mathrm{e}[\operatorname{kissing}(\mathrm{e}) \& \operatorname{Agent}(\mathrm{e})=\mathrm{m} \& \operatorname{Theme}(\mathrm{e})=\mathrm{c}]$

f. $\quad \exists e[\operatorname{kissing}(e) \& \operatorname{Agent}(e)=\mathrm{m} \& \operatorname{Theme}(\mathrm{e})=\mathrm{c}]$

The interpretation of the passive example proceeds similarly. For exposition we assume a simple passive structure as in (64), which yields the same interpretation, in (65).

(64)

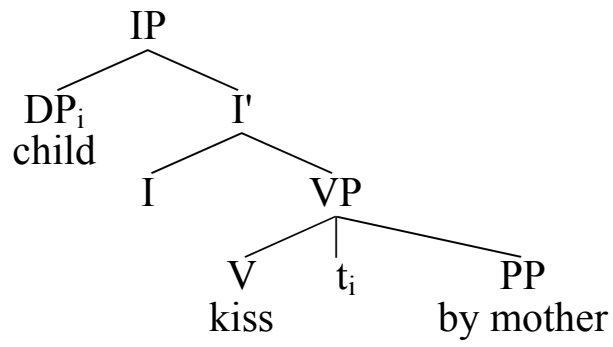


(65) a. kiss $\lambda \mathrm{y} \lambda \mathrm{x} \lambda \mathrm{e}$ [kissing(e) \& $\operatorname{Agent}(\mathrm{e})=\mathrm{x} \& \operatorname{Theme}(\mathrm{e})=\mathrm{y}]$

b. VP $\lambda y \lambda x \lambda e[\operatorname{kissing}(e) \& \operatorname{Agent}(e)=x \&$ Theme $(e)=y](m)(z) \rightarrow$

$\lambda \mathrm{e}[\mathrm{kissing}(\mathrm{e}) \& \operatorname{Agent}(\mathrm{e})=\mathrm{m} \& \operatorname{Theme}(\mathrm{e})=\mathrm{z}]$

c. I' $\quad \lambda z \lambda \mathrm{e}[\mathrm{kissing}(\mathrm{e}) \& \operatorname{Agent}(\mathrm{e})=\mathrm{m} \&$ Theme $(\mathrm{e})=\mathrm{z}]$

d. IP $\lambda z \lambda$ e $[$ kissing(e) \& Agent $(\mathrm{e})=\mathrm{m} \&$ Theme $(\mathrm{e})=\mathrm{z}](\mathrm{c}) \rightarrow$

$\lambda \mathrm{e}[\operatorname{kissing}(\mathrm{e}) \& \operatorname{Agent}(\mathrm{e})=\mathrm{m} \& \operatorname{Theme}(\mathrm{e})=\mathrm{c}]$

e. $\quad \exists$ e $[\operatorname{kissing}(\mathrm{e}) \& \operatorname{Agent}(\mathrm{e})=\mathrm{m} \&$ Theme $(\mathrm{e})=\mathrm{c}]$

Now we insert mau 'want' into the passive structure. The syntactic structure of the crossed reading use of mau/ingin is simply the passive example (64) with the auxiliary verb inserted into a VP about the main verb phrase, as we proposed in section 3.3 (see (47)):

anak itu mau/ingin di-cium oleh ibu

child that want PASs-kiss by mother

'The mother wants to kiss the child.'

(67)

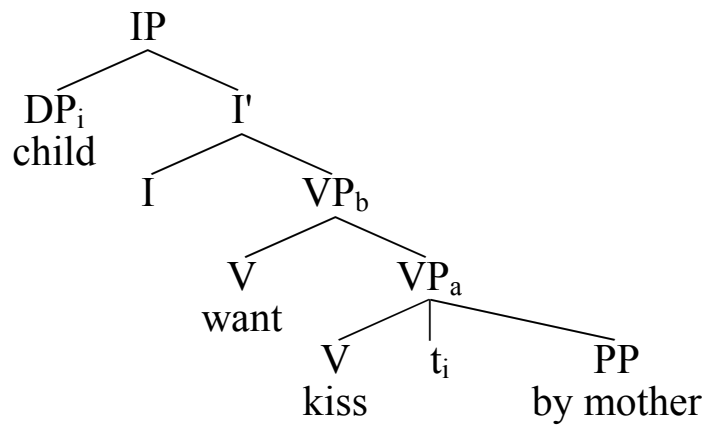

The correct interpretation relies crucially on the semantics that we assign to mau/ingin, in (68).

$$
\lambda \mathrm{P} \lambda \mathrm{s}\left[\operatorname{want}(\mathrm{s}) \& \operatorname{Goal}(\mathrm{s}){ }^{\wedge} \exists \mathrm{e}(\mathrm{P}(\mathrm{e}) \& \operatorname{volition}(\mathrm{e})=\text { Experiencer(s) })\right]
$$


'Want' is a one-place predicate that takes as its single argument a proposition (Heim, 1992; Pustejovsky, 1995, among many others), which we call the Goal. This Goal coincides with the desired state of affairs. This argument structure is consistent with the raising syntax of 'want' discussed above; the proposition is realized as the VP complement in (67). The semantics of 'want' then explicitly picks out the volitional participant in this proposition and identifies it as the experiencer of wanting. 'Want' does this without actually taking this DP as its argument.

The interpretation of the CCC in (67) is determined as follows. The passive VP has the same interpretation as above. Because the volitional property of the Agent will be relevant, it has been reintroduced into the meaning of kiss (see (61)).

(69)a. kiss $\lambda y \lambda x \lambda e[$ kissing(e) \& $\operatorname{Agent}(\mathrm{e})=\mathrm{x} \& \operatorname{volition}(\mathrm{e})=\mathrm{x} \&$ Theme $(\mathrm{e})=\mathrm{y}]$

b. $\operatorname{VP}_{\mathrm{a}} \quad \lambda \mathrm{y} \lambda \mathrm{x} \lambda \mathrm{e}[\operatorname{kissing}(\mathrm{e}) \& \operatorname{Agent}(\mathrm{e})=\mathrm{x} \& \operatorname{volition}(\mathrm{e})=\mathrm{x} \& \operatorname{Theme}(\mathrm{e})=\mathrm{y}](\mathrm{m})(\mathrm{z}) \rightarrow$ $\lambda \mathrm{e}[\operatorname{kissing}(\mathrm{e}) \& \operatorname{Agent}(\mathrm{e})=\mathrm{m} \& \operatorname{volition}(\mathrm{e})=\mathrm{m} \& \operatorname{Theme}(\mathrm{e})=\mathrm{z}]$

c. want $\lambda \mathrm{P} \lambda \mathrm{s}\left[\operatorname{want}(\mathrm{s}) \& \operatorname{Goal}(\mathrm{s})={ }^{\wedge} \exists \mathrm{e}(\mathrm{P}(\mathrm{e}) \& \operatorname{volition}(\mathrm{e})=\operatorname{Experiencer}(\mathrm{s}))\right]$

d. $\quad \mathrm{VP}_{\mathrm{b}} \quad \lambda \mathrm{P} \lambda \mathrm{s}\left[\operatorname{want}(\mathrm{s}) \& \operatorname{Goal}(\mathrm{s})={ }^{\wedge} \exists \mathrm{e}(\mathrm{P}(\mathrm{e}) \& \operatorname{volition}(\mathrm{e})=\operatorname{Experiencer}(\mathrm{s}))\right]\left(\mathrm{VP}_{\mathrm{a}}\right) \rightarrow$ $\lambda \mathrm{P} \lambda \mathrm{s}\left[\operatorname{want}(\mathrm{s}) \& \operatorname{Goal}(\mathrm{s})={ }^{\wedge} \exists \mathrm{e}(\mathrm{P}(\mathrm{e}) \& \operatorname{volition}(\mathrm{e})=\operatorname{Experiencer}(\mathrm{s}))\right](\lambda \mathrm{e}[\operatorname{kissing}(\mathrm{e}) \& \operatorname{Agent}(\mathrm{e})=\mathrm{m} \&$ $\operatorname{volition}(\mathrm{e})=\mathrm{m} \&$ Theme $(\mathrm{e})=\mathrm{z}]) \rightarrow$ $\lambda \mathrm{s}\left[\operatorname{want}(\mathrm{s}) \& \operatorname{Goal}(\mathrm{s})=^{\wedge} \exists \mathrm{e}\left(\lambda \mathrm{e}^{\prime}\left[\operatorname{kissing}\left(\mathrm{e}^{\prime}\right) \& \operatorname{Agent}\left(\mathrm{e}^{\prime}\right)=\mathrm{m} \& \operatorname{volition}\left(\mathrm{e}^{\prime}\right)=\mathrm{m} \& \operatorname{Theme}\left(\mathrm{e}^{\prime}\right)=\mathrm{z}\right](\mathrm{e}) \&\right.\right.$ $\operatorname{volition}(\mathrm{e})=$ Experiencer(s)]

e. IP $\lambda z \lambda s\left[\operatorname{want}(\mathrm{s}) \& \operatorname{Goal}(\mathrm{s})={ }^{\wedge} \exists \mathrm{e}[\operatorname{kissing}(\mathrm{e}) \& \operatorname{Agent}(\mathrm{e})=\mathrm{m} \& \operatorname{volition}(\mathrm{e})=\mathrm{m} \&\right.$ Theme $(\mathrm{e})=\mathrm{z} \& \operatorname{volition}(\mathrm{e})=$ Experiencer(s)]](c) $\rightarrow$ $\lambda \mathrm{s}\left[\operatorname{want}(\mathrm{s}) \& \operatorname{Goal}(\mathrm{s})={ }^{\wedge} \exists \mathrm{e}[\operatorname{kissing}(\mathrm{e}) \& \operatorname{Agent}(\mathrm{e})=\mathrm{m} \& \operatorname{volition}(\mathrm{e})=\mathrm{m} \& \operatorname{Theme}(\mathrm{e})=\mathrm{c} \& \operatorname{volition}(\mathrm{e})=\right.$ Experiencer(s)]]

f. $\quad \exists \mathrm{s}\left[\operatorname{want}(\mathrm{s}) \& \operatorname{Goal}(\mathrm{s})^{=} \exists \mathrm{e}[\operatorname{kissing}(\mathrm{e}) \& \operatorname{Agent}(\mathrm{e})=\mathrm{m} \& \operatorname{volition}(\mathrm{e})=\mathrm{m} \&\right.$ Theme $(\mathrm{e})=\mathrm{c} \&$ Experiencer $(\mathrm{s})=\mathrm{m}]]$ 
The resulting interpretation in (69f) is that there is a propositional goal such that it holds true in all the worlds compatible with an event of the mother kissing the child and a state of wanting in which the mother wants the event. In other words, the mother wants it to be true that she experiences the state in which she kisses the child. This is the desired interpretation. Observe that the 'wanter' is determined semantically as the participant who is the volitional Agent in the propositional argument. As a result, 'want' can assign a thematic property to a participant without assigning it a $\theta$-role and without it being an argument of 'want'.

Our analysis predicts that the syntactic realization of the passive VP is not important to the construction. All that matters is that the passive VP contain a volitional Agent. This result is verified internal to Indonesian. We have already seen that Indonesian has a second, bare passive, repeated in (70), in which the embedded verb appears in an uninflected form and the passive agent is proclitic to the verb.

$$
\begin{aligned}
& \text { bagian kalimat ini dia=tegaskan } \\
& \text { section sentence this } 3 \mathrm{SG}=\text { emphasize } \\
& \text { 'This part of the sentence was emphasized by him.' }
\end{aligned}
$$

This passive can also be embedded under mau to yield the crossed reading:

(71) bagian kalimat ini mau dia=tegaskan
section sentence this want $3 \mathrm{SG}=$ emphasize
'He wants to emphasize this part of the sentence.'

On the other hand, Indonesian has another, passive-like prefix ter-, with a variety of functions (Sneddon, 1996:112-120). It typically indicates a state or an accidental/involuntary 
action. If an agent can be expressed, it is interpreted as non-volitional (Arka and Manning, 1998:(10b)):

obat itu ter-makan oleh anak itu

medicine that TER-eat by child that

'The medicine was unintentionally taken by the child.'

Our analysis correctly predicts that such verbs should be impossible in the VP complement of the $\mathrm{CCC}$ because there is no volitional participant:

$$
\begin{aligned}
& \text { *surat ini ingin ter-baca oleh Amir } \\
& \text { letter this want TER-read by Amir } \\
& \text { ('Amir wants to read this letter.') }
\end{aligned}
$$

In fact, the embedded VP need not even be passive. We hypothesize that an active example such as (1), repeated below as (74), can involve the auxiliary use of mau, as nothing rules this out. ${ }^{12}$ In such cases, the volitional agent and the surface subject align so it is not possible to distinguish such examples from an ordinary control use of mau, which we believe may also exist. ${ }^{13}$

\footnotetext{
${ }^{12}$ Cinque (2004) argues that in Italian, even apparent control cases with 'want' (and 'seem') can be reduced to raising.

13 A number of colleagues and reviewers have pointed out the importance of determining the structure of the ordinary non-crossed use in (74). Is it a standard control structure (with PRO), does it also make use of the raising structure, or is it structurally ambiguous? If it is a control structure, it should have different syntactic behavior from what we have documented for the
} 
anak itu mau/ingin men-cium ibu

child that want ACT-kiss mother

The child wants to kiss the mother.'

We leave for future investigation what other kinds of predicates can embed under mau/ingin.

\section{Conclusions}

Unusual properties associated with the verb 'want' are known from such familiar languages as English and Romance, and Indonesian 'want' is no less challenging. As we have shown, Indonesian verbs meaning 'want', mau and ingin, participate in a Crossed Control Construction in which the alignment of the two overt arguments with their predicates is "crossed". The experiencer of wanting is in the embedded clause and the theme of the embedded verb appears as the subject of the matrix clause:

$$
\begin{aligned}
& \text { bagian kalimat ini mau di-tegaskan oleh guru } \\
& \text { section sentence this want PASS-emphasize by teacher } \\
& \text { 'The teacher wants to emphasize this part of the sentence.' }
\end{aligned}
$$

For the syntax of this construction, we argued that 'want' is an auxiliary verb with raising of the theme argument from the complement. In our account the embedded agent is not an argument of 'want' at all. Our analysis is quite similar to the structure of clauses headed by auxiliaries in

CCC and should behave more similarly to mencoba 'try' and other control verbs, which the language does seem to have. Time and space considerations have prevented us from exploring the structure of the ordinary use of mau/ingin. We leave that for future research. 
Tzotzil (Aissen, 1994) or recent analyses of functional verbs, including 'want', in Italian (Cinque, 2004). It remains to be seen if the proposed analysis of crossed control can also be extended to other Austronesian languages, which show similar patterns.

Despite a raising syntax, the control semantics in the CCC is quite robust. We proposed to account for the interpretation of the CCC with the lexical semantics of 'want'. Although 'want' has only one (propositional) argument, it ascribes an experiencer thematic property to the volitional argument within this proposition, making it the 'wanter'. This move is different from assigning a $\theta$-role to that participant as such $\theta$-role assignment would violate basic locality principles of $\theta$-role assignment. The thematic relationship between 'want' and the Agent of its complement is located outside its predication structure.

The analysis raises a pressing set of issues: If thematic relationships can be constructed in the lexical semantics in this way using thematic properties distinct from $\theta$-roles, linguistic theory needs to develop principled ways of constraining such relationships. First, what types of thematic dependencies can be established outside $\theta$-roles? Second, whereas $\theta$-role assignment has always been assumed to be local, thematic properties ascribed to a referent beyond $\theta$-roles can be less local, as seen here. How much distance should be possible in such associations?

\section{Acknowledgments}

We would like to thank our language consultants Ignatius Cahyanto, Ka Mi Jong, Marian Kata, Yassir Tjung, and Regina Yanti. The semantic analysis we tentatively pursued here was very much aided by discussions with Ivano Caponigro and Gennaro Chierchia. We are grateful for feedback from and helpful discussions with Judith Aissen, Sandy Chung, Guglielmo Cinque, Peter Cole, Shin Fukuda, David Gil, Grant Goodall, Gabriella Hermon, Peter Sells, the audience 
at ISMIL 10, and two anonymous Lingua reviewers. We regret that we were unable to take into account all of their excellent suggestions. This work is supported by NSF grants BCS-0131946 and BCS-0131993.

\section{References}

Aissen, J. L. 1994. Tzotzil auxiliaries. Linguistics 32, 657-690.

Aissen, J., Perlmutter, D. M. 1983. Clause reduction in Spanish. In: Perlmutter, D. M. (Ed.). Studies in Relational Grammar. 1. The University of Chicago Press, Chicago, pp. 360403.

Arka, I. 2000. Control and argument structure: Explaining control into subject in Indonesian. $\begin{array}{lll}\text { Manuscript, } & \text { Australia } & \text { Nniversity, }\end{array}$ http://eprints.anu.edu.au/archive/00002221/01/Arka_control.pdf.

Arka, I W., Manning, C. D. 1998. Voice and grammatical relations in Indonesian: A new perspective. In: Butt. M., King, T. H. (Eds.), Proceedings of the LFG98 Conference. CSLI Publications, Stanford, Ca. http://csli-publications.stanford.edu/LFG/3/arkamanning.html.

Belletti, A., Rizzi, L. 1988. Psych-verbs and $\Theta$-Theory. Natural Language and Linguistic Theory $6,291-352$.

Chomsky, N. 1981. Lectures on Government and Binding. Foris, Dordrecht.

Chung, S. 1976. On the subject of two passives in Indonesian. In: Li, C. N. (Ed.), Subject and Topic. Academic Press, New York, New York, pp. 57-98.

Chung, S. this volume. Indonesian clause structure from an Austronesian perspective. 
Cinque, G. 2004. Restructuring and functional structure. In: Belletti, A. (Ed.), Structures and Beyond. The Cartography of Syntactic Structures, Vol. 3. Oxford University Press, New York, pp.132-191.

Cole, P., Hermon, G. 2005. Subject and non-subject relativization in Indonesian. Journal of East Asian Linguistics 14, 59-88.

Cole, P., Hermon, G., Tjung, Y. 2005. How irregular is wh in situ in Indonesian? Studies in Language 29, 553-581.

Davidson, D. 2001. Essays on Actions and Events. Oxford University Press, Oxford.

Den Dikken, M., Larson R., Ludlow, P. 1996. Intensional 'transitive' verbs and concealed complement clauses. Rivista di Linguistica 8, 331-348.

DiSciullo, A.-M., Rosen, S. 1991. Constructions with light and quasi-light verbs. Revue Quebecoise de Linguistique 20, 13-37.

Dowty, D. 1991. Thematic proto-roles and argument selection. Language 67, 547-619.

Ernst, T. 2002. The Syntax of Adjuncts. Cambridge University Press, Cambridge.

Gil, D. 2002. The prefixes di- and n- in Malay/Indonesian dialects. In: Wouk, F., Ross, M. (Eds.), The History and Typology of West Austronesian Voice Systems. Pacific Linguistics, Canberra, pp. 241-283.

Goodall, G. 1991. Wanna-contraction as restructuring. In: Georgopoulos, C., Ishihara, R. (Eds.), Interdisciplinary Approaches to Language: Essays in Honor of S.-Y. Kuroda. Kluwer, Dordrecht, pp. 326-345.

Grimshaw, J. 1990. Argument Structure. MIT Press, Cambridge, Ma.

Heim, I. 1992. Presupposition projection and the semantics of attitude verbs. Journal of Semantics 9, 183-221. 
Heim, I., Kratzer, A. 1998. Semantics in Generative Grammar. Blackwell, Malden, Ma.

Jackendoff, R. 1972. Semantic Interpretation in Generative Grammar. MIT Press, Cambridge, Ma.

Lakoff, G. 1970. Irregularity in Syntax. Holt, Rinehart, and Winston, New York, New York.

Lobeck, A. 1992. Licensing and identification of ellipted categories in English. In: Berman, S., Hestvik, A. (Eds.), Proceedings of the Stuttgart Ellipsis Workshop. Stuttgart, Germany.

Manzini, M. R. 1983. Restructuring and Reanalysis. Ph.D. dissertation, MIT.

McConnell-Ginet, S. 1982. Adverbs and logical form. Language 58, 144-184.

Mosel, U., Hovdhaugen, E. 1992. Samoan Reference Grammar. Scandinavian University Press, Oslo.

Musgrave, S. 2001. Non-Subject Arguments in Indonesian. Ph.D. dissertation, University of Melbourne.

Otsuka, Y. 2000. Ergativity in Tongan. Ph.D. dissertation, University of Oxford.

Parsons, T. 1990. Events in the Semantics of English. MIT Press, Cambridge, Ma.

Pesetsky, D. 1995. Zero Syntax. MIT Press, Cambridge, Ma.

Picallo, M. C. 1990. Modal verbs in Catalan. Natural Language and Linguistic Theory 8, 285312.

Polinsky, M., Potsdam, E. 2002. Backward Control. Linguistic Inquiry 33, 245-282.

Postal, P., Pullum, G. 1978. Traces and the description of English complementizer contraction. Linguistic Inquiry 9, 1-29.

Potsdam, E. 2006. Backward object control in Malagasy and principles of chain reduction. Manuscript, University of Florida.

Pullum, G. 1997. The morpholexical nature of English to-contraction. Language 73, 79-102. 
Pustejovsky, J. 1995. The Generative Lexicon. MIT Press, Cambridge, Ma.

Rizzi, L. 1982. Issues in Italian Syntax. Foris, Dordrecht.

Saddy, D. 1991. Wh-scope mechanisms in Bahasa Indonesia. In: Cheng, L., Demirdashe, H. (Eds.), More Papers on Wh-Movement. (MIT Working Papers in Linguistics 15.), Cambridge, Mass., pp. 183-218.

Sneddon, J. 1996. Indonesian: A Comprehensive Grammar. Routledge, London.

Strozer, J. 1981. An alternative to restructuring in Romance syntax. In: Contreras, H., Klausenberger, J. (Eds.), Proceedings of the Tenth Anniversary Symposium on Romance Linguistics, University of Washington, Seattle, pp. 177-184.

Tenny, C. 1998. Psych verbs and verbal passives in Pittsburghese. Linguistics 36, 591-597.

Vamarasi, M. 1999. Grammatical Relations in Bahasa Indonesia. Pacific Linguistics, Canberra.

Wechsler, S. Arka, I. W. 1998. Syntactic ergativity in Balinese: An argument structure based theory. Natural Language and Linguistic Theory 16, 387-441.

Wurmbrand, S. 2003. Infinitives: Restructuring and Clause Structure. Mouton de Gruyter, Berlin.

Wyner, A. Z. 1994. Boolean Event Lattices and Thematic Roles in the Syntax and Semantics of Adverbial Modification. Ph.D. dissertation, Cornell University.

Wyner, A. Z. 1998. Subject-oriented adverbs are thematically dependent. In: Rothstein, S. (Ed.), Events and Grammar, Kluwer, Dordrecht, pp. 333-348. 